\title{
Reografiar
}

Malaysian Journal of Society and Space

\section{Does gamification work in a serious context? The influence of gamification, utilitarian, and hedonic features in the community-based crowdfunding platform}

\author{
Nur Aqilah Hazirah Mohd Anim¹, Nor Asiah Omar ${ }^{2}$ \\ ${ }^{1}$ Faculty of Economics and Muamalat, Universiti Sains Islam Malaysia \\ ${ }^{2}$ Fakulti Ekonomi dan Pengurusan, Universiti Kebangsaan Malaysia \\ Correspondence: Nor Asiah Omar (email: norasiah@ukm.edu.my)
}

Received: 28 September 2020; Accepted: 25 January 2021; Published: 29 May 2021

\begin{abstract}
Crowdfunding can provide financial aid to the underserved in a fast and safe manner. With the diffusion of technology, more people have relied on online crowdfunding platforms to fund their projects. However, researchers have found that contributors' willingness to support the projects on crowdfunding platforms financially has been on the decline. This study aimed to investigate the ability of crowdfunding platform features to influence the intentions of potential contributors to donate on the platform. This research proposed three variables based on economic utility theory, flow theory, and persuasive theory: utilitarian features; hedonic features; and gamification features. Due to the nascent stage of the crowdfunding environment in Malaysia, this study managed to collect 176 valid responses through virtual snowball sampling method. SPSS was employed to test the three hypotheses. The empirical findings reveal that utilitarian features were the most crucial factor in driving contributors' intention to participate in a crowdfunding project. Hedonic and gamification features, on the other hand, do not directly influence contributors' behavior. Theoretically, this study enriches the literature on human-computer interaction by examining the role of the crowdfunding platform to attract potential contributors and enhances the understanding of the implementation of gamification in the crowdfunding platform. Finally, this research suggests that future studies should conduct research that specifically involves advanced game-like settings to investigate the real potential of gamification in crowdfunding activities.
\end{abstract}

Keywords: Crowdfunding, flow theory, gamification, hedonic, persuasive theory, utilitarian. 


\section{Introduction}

The acceleration of technology in recent decades has introduced a new way of fundraising. Previously, people channeled their donations through religious centers or other traditional organizations. With the benefit of the Internet, people began to be able to raise funds and donate through crowdfunding platforms. The function of this type of platform was to create a bridge between fund seekers and contributors. It enabled individuals and organizations to reach the potential contributors by posting their projects on the platform.

A project on a crowdfunding platform is not restricted only to helping people who are in great distress; it also provides a place to seek funds for other project types, such as civic crowdfunding, where contributors can support projects related to community service (Stiver et al., 2015). As the crowdfunding platform is online-based, it has been able to reach millions of people around the world who can donate through a platform and overcome geographical barriers (Agrawal et al., 2015) and much faster than with conventional fundraising (Argo et al., 2020). Based on the nature of the crowdfunding activities, researchers have categorized crowdfunding into four types: donation, reward, equity, and lending-based crowdfunding (Adhikary et al., 2018). However, some researchers have argued that crowdfunding should be understood and categorized into two categories based on the motivation of the contributors: community-based crowdfunding and investment-based crowdfunding (Collins \& Pierrakis, 2012).

Although community-based crowdfunding has achieved tremendous development in recent years, several researchers have noticed that participation by donors has been decreasing (Forbes \& Schaefer, 2017; Lukkarinen et al., 2016; Mariani et al., 2017; Mollick, 2014; Zhang \& Chen, 2019; Zhao et al., 2017). Further, the providers have been withdrawing after their first participation and reluctant to become consistent funds providers (Aitamurto, 2011; Burtch et al., 2013; Choy \& Schlagwein, 2016; Jian \& Shin, 2015; Kuppuswamy \& Bayus, 2018). Thus, this research has investigated the factors that influence contributors' intentions to channel their donations using a crowdfunding platform.

Crowdfunding platforms are two-sided, with the platform as the intermediary between the fund seeker and the fund provider(Haas et al., 2014). Researchers have attempted to study the intentions of contributors, but their research concentrated on the factors that relate to the credibility of the fund seekers and the project's characteristics (Kang et al., 2016; Rodriguez-Ricardo et al., 2018; Wang \& Yang, 2019) However, the role of a crowdfunding platform in influencing fund seekers' intention remained as an unexplored domain. Meanwhile, crowdfunding platforms are critical players in providing the mechanism and tools to develop social connections that create relationships in the crowdfunding community (Lacan \& Desmet, 2017).

Moreover, the previous research in the crowdfunding domain concentrated on understanding the utilitarian and hedonic features of the proposed projects but fewer researches elaborate on the effect of such features embedded on the platform and the ability to attract potential contributors (Jiang et al., 2020; Zhao \& Vinig, 2017). In addition, since gamification is a relatively new concept in crowdfunding activities, understanding this concept is crucial to interpret contributors' perceptions towards game-like activities in crowdfunding platforms (Behl \& Dutta, 2020). Furthermore, researchers agreed that the implementation of technology in financial activities could enhance efficiency and effectiveness of the system (Kuznetsov, 2020). Thus, in the perspectives of crowdfunding, enhancing the crowdfunding platform with technological advance features such as gamification will contribute to more successful projects. 


\section{Literature review}

\section{Utilitarian Features}

The user of a platform has his or her own goals when participating in a crowdsourcing platform and is assisted by the utilitarian features of the platform (Jamshidi et al., 2018). Utilitarianism has its roots in Stigler's economic utility theory, which stated that individual preferences in achieving their utilitarian goals can be measured based on monetary or functional terms (Jamshidi et al., 2018; Kim et al., 2011). An online shopping website, for example, should include product and price comparisons, be time-saving and easy to use, and able to complete its task, which are all utilitarian features that help users to achieve their objectives (Childers et al., 2001; Ozturk et al., 2016). The utilitarian features of a website should be easily accessible and effectively help the user find information (Rakjit \& Lertputtarak, 2019).

For this research, the utilitarian perspectives of a crowdfunding platform include the layout of the platform, which provides the information and objectives of the project (Belleflamme et al., 2015; Choy \& Schlagwein, 2016; Polzin et al., 2018), and the images and videos that convince visitors to the site of the legitimacy of the project (Aprilia \& Wibowo, 2017; Kim et al., 2016). By incorporating such design in a crowdfunding platform, a potential fund can provide a layout so that the fund donors can empathize with the target beneficiaries and, thereby, maximize their contributions (Althoff \& Leskovec, 2015; Gleasure \& Feller, 2016), as well as making them feel like active members of a like-minded donor community (Choy \& Schlagwein, 2016).

\section{Hedonic Features}

Then, researchers have argued that utilitarian features are insufficient to influence user-intended behavior (Bilgihan et al., 2014; Bridges \& Florsheim, 2008). A website or platform that is targeted to receive a financial contribution from the users' needs to accomplish these well-defined functional goals and appeal to positive sensory feelings of the donor (Bly et al., 1998; Venkatesh \& Brown, 2001). On the crowdfunding platform, utilitarian factors in the platform did influence individual participation and suggests including affective dimensions, such as perceived enjoyment and desires, which represent hedonic features (Lacan \& Desmet, 2017).

The process of enjoyment is embedded in the flow theory Csikszentmihalyi (1997), in which people become highly involved in the actual activity on the website (Scholl-Grissemann \& Schnurr, 2016). Hedonic features help the user make the process fun and enjoyable while performing the task (Ha \& Stoel, 2009). While utilitarian applications focus on efficiency, hedonic applications employ animated images and focus on colors, sounds, and appealing visual layouts that make the user happy and involved while browsing the website. The integration of hedonic features in a website or platform can result in positive behavioral intention, such as consumer buying intention, loyalty, satisfaction, and word of mouth promotion (Vieira et al., 2018).

Nevertheless, some researchers have found that hedonic features are less critical than utilitarian features (Hazari et al., 2017). Moreover, hedonic features can be a distraction for the user when it involves a risky activity, such as performing an online transaction. The online banking community, for example, has emphasized fulfilling the utilitarian motivation and disregarding enjoyable experiences while browsing the website (Yaseen \& El Qirem, 2018). Based on these findings, the issue still arises in the crowdfunding context, which website features would significantly influence users' intention to donate using a crowdfunding platform. 


\section{Gamification}

Another relatively new factor in this study is gamification. Recent studies have introduced gamification as a new feature that may influence an individual to use a platform. Gamification refers to the use of game design elements in a non-game context (Deterding et al., 2011). Elearning was an early non-game activity that adopted gamification into the function (Bartel \& Hagel, 2014). Recently, banking, e-commerce, and investment applications such as robo-advisory have implemented game elements into their websites, embracing persuasive theory to encourage the user to participate in the intended behavioral exercise (Bartel \& Hagel, 2014; Fogg, 2009).

Scholars have described gamification as the use of game elements, mechanics, features, design, and structure in a non-game environment or context (Attali \& Arieli-Attali, 2015; Bruder, 2015; Dale, 2014; Hamari et al., 2014; Hanus \& Fox, 2015; Isaacs, 2015; Powers et al., 2013). Various game elements in pure game settings have been adapted to the non-game context such as leader boards, challenges, rewards systems, and others. Researchers have conceptualized the game elements into two types based on the complexity of the implementation (Liu et al., 2017). The first category of a gamification object refers to visual and non-visual features embedded on the website. For example, graphics, audio clips, avatars, virtual items, artificial characters, storylines, badges, and leader-boards. These elements are the fundamental components in gamification design, and the ones most likely to be incorporated into a website (Landers et al., 2017; Mekler et al., 2013). The second category is gamification mechanics, which is a higher level of design that requires a proper system to implement. Examples of the features are level systems, point systems, quests, competition and collaboration, in-game economy, and social networking features.

More recent research has conceptualized gamification into three categories, based on the function of the game elements (Xi \& Hamari, 2020). Immersion-related features try to immerse the player in self-directed, inquisitive activity, including game mechanics such as avatars, storytelling, narrative structures, roleplay mechanics, and so forth. Achievement-related features are designed to enhance the players' sense of accomplishment and include game mechanics such as badges, challenges, missions, goals, leaderboards, progression metrics, etc. Social interactionrelated features have been primarily used to enable a user's social interaction (Jang et al., 2018), and include game mechanics such as team, group, and competition (Hamari \& Tuunanen, 2012; Koivisto \& Hamari, 2019). The application of gamification in the crowdfunding context is still at an early stage, and most of the crowdfunding platforms have used basic game elements like a progress bar, avatar, and leader-boards to encourage fund provider participation.

\section{Hypotheses development}

In explaining the research framework (Figure 1), previous researchers agreed that utilitarian and hedonic features usually goes hand in hand hence appeared in a single framework (e.g. Babin et al., 1994b; Bridges \& Florsheim, 2008; Hsu \& Chen, 2018). The relationship of utilitarian and hedonic features in predicting positive behavioral outcomes in online platform usage confirmed in several previous researches conducted in an online environment related to website usage (Bilgihan et al., 2016; Bilgihan \& Bujisic, 2015; Wu \& Holsapple, 2014). Furthermore, utilitarian and hedonic features are important to lead a casual visitor of the website to conduct the intended positive behavior (Zheng et al., 2019). Thus, enhancing utilitarian and hedonic features 
in a crowdfunding platform could influence the fund seekers' intention to proceed with positive behavior.

Furthermore, the user of an online platform driven by utilitarian and hedonic motivation to consume technology-based services (Cruz-Cárdenas et al., 2021), the representation of utilitarian and hedonic features embedded in the website helps the user to achieve their objectives. The visitor of the crowdfunding platform has the intention of donating to the crowdfunding projects. The appearance of functional utilitarian and hedonic features thus assists the visitor to proceed with their donation.

In terms of gamification features, it has become a trend in the marketing field because it can drive customers' behavior and motivate them in task performance (Hsu et al., 2017; Koivisto \& Hamari, 2019). The research related to gamification in the crowdfunding context is still limited. Kontogiannidis et al., (2017) being the prior researchers confirmed the positive relationship between gamification and intention to use a crowdfunding platform. The finding concurred by other researchers by incorporating gamification has been proven to enhance participation on websites specifically in e-commerce and location check in mobile application (Hamari et al., 2014; Kim \& Ahn, 2017; Thiel \& Fröhlich, 2017). For example, a point mechanism system, one of the gamification features, could help to achieve civic engagement (stay longer) in online crowdfunding platforms (Burtch et al., 2018). Based on the arguments, this study proceeds the following hypotheses.

H1: Utilitarian Features in crowdfunding platform has a positive influence on donation intention using the crowdfunding platform.

$\mathrm{H} 2$ : Hedonic Features has a positive influence on donation intention using the crowdfunding platform.

H3: Gamification Features has a positive influence on donation intention using the crowdfunding platform

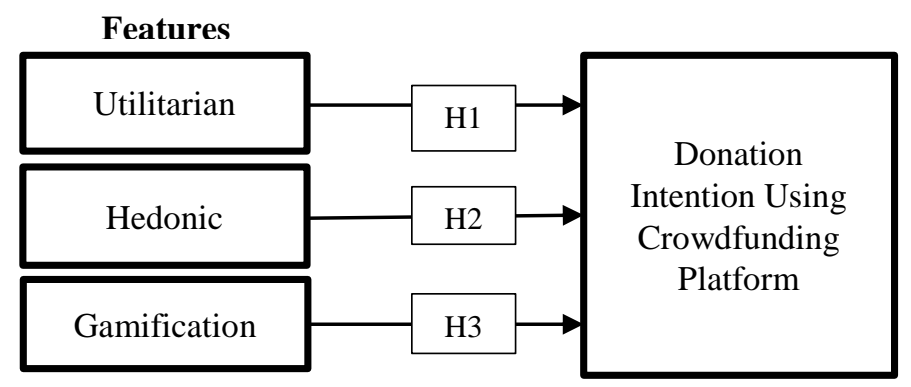

Figure 1. Research Framework

\section{Method and study area}

\section{Design and participation}

This study to collect information from individuals who had a general knowledge of crowdfunding and were aware of crowdfunding platforms. Because the crowdfunding environment in Malaysia is at an early stage, this study employed a virtual snowball sampling method to reach the respondents. To reach the respondents, the researcher browsed through pages and accounts related to crowdfunding on Facebook and Twitter. Then, the targeted respondents received a link to the 
survey, which they could then complete. Then, they will have the opportunity to recommend any of their acquaintances to be contacted. Using this data collection method, this study collected 176 respondents that fulfilled the requirements. More than half of the respondents are female (58.8\%), the majority age range falls between $18-25$ years $(68.8 \%)$ and most of the respondents are students $(55.7 \%)$.

When answering the survey, the respondents needed to focus on the particular crowdfunding platform with which they were familiar, Table 1 present the crowdfunding platform chose by the respondents. The crowdfunding platforms in this study were community-based crowdfunding projects that covered donations and reward crowdfunding categories. In addition, all the crowdfunding platforms in this study had gamification elements embedded in the platform.

\section{Measurement}

The questionnaire contained three parts. The first part had filtering questions and general information to identify the respondents' current understanding of crowdfunding and their eligibility to participate in this study. The second part had the measurements of variables, including gamification features, utilitarian features, hedonic features, and intention to donate using the crowdfunding platform. The last part of the questionnaire was intended to collect the respondents' demographic information, such as age, income, employment, and others.

The questionnaire was designed using items from past research. All variables used the seven-point Likert scale from $1=$ strongly agree to $7=$ strongly disagree and was measured as a unidimensional construct. The predictors variables, gamification features were measured using ten items by (Cózar-Gutiérrez \& Sáez-López, 2016; Kontogiannidis et al., 2017; Rodrigues et al., 2016). The measurement for utilitarian features, was adapted from the work of (Babin et al., 1994a; Bilgihan \& Bujisic, 2015; Ettis \& Haddad, 2019). Additionally, hedonic features was comprised of 7 items adopted from (Babin et al., 1994b; Bilgihan \& Bujisic, 2015; Han et al., 2018). Donation intention included 6 items in the crowdfunding platform and was adapted from (W. Y. Wu et al., 2013).

Table 1. List of crowdfunding platform in the study.

\begin{tabular}{ccc}
\hline Crowdfunding Platform & Type of Project & Frequency \\
\hline JomDonate & Philanthropic & 51 \\
SkolaFund & Education & 46 \\
PitchIN & Innovation & 23 \\
GlobalSadaqah & Philanthropic & 19 \\
KitaFund & Medical Assistant & 14 \\
GoFundMe & Philanthropic & 11 \\
GoGetFunding & Philanthropic & 6 \\
Mystartr & Community & 6 \\
\hline
\end{tabular}

\section{Results and discussion}

Data were analyzed using the Statistical Package for Social Sciences (SPSS25.0). A reliability test was conducted and showed that the Cronbach alpha for all variables surpassed the acceptable range. Utilitarian features was 0.885 , hedonic features was 0.931 , gamification features was 0.903 , 
and donation intention was 0.935 and all were considered as having a relatively high internal consistency (Cortina, 1993).

Standard multiple regression was used to assess the ability of utilitarian features, hedonic features, and gamification features to influence donation intention. The multiple regression analysis showed that one hypothesis was accepted, and the other two hypotheses were rejected. The ANOVA model showed that the three factors explained $44 \%$ of the variance in donation intention $(\mathrm{R}$ square $=.44, \mathrm{~F}(3,172)=45.992, \mathrm{p}<.05)$. Utilitarian features (H2) were statistically significant with donation intention (beta $=.523, \mathrm{p}<.05)$. Meanwhile, gamification (H1) and hedonic features (H3) were statically insignificant and did not influence donation intention. Table 2 represents the result of the analysis.

Table 2. Result of Multiple Regression Analysis.

\begin{tabular}{|c|c|c|c|c|c|c|}
\hline \multirow{2}{*}{ Variable } & \multicolumn{2}{|c|}{$\begin{array}{l}\text { Unstandardized } \\
\text { Coefficient }\end{array}$} & \multirow{2}{*}{$\begin{array}{c}\begin{array}{c}\text { Standardized } \\
\text { Coefficients }\end{array} \\
\text { Beta }\end{array}$} & \multirow{2}{*}{ t-value } & \multirow{2}{*}{ p-value } & \multirow{2}{*}{ Decision } \\
\hline & Beta & Std. Error & & & & \\
\hline $\begin{array}{l}\text { Model } \\
\text { (constant) }\end{array}$ & .894 & .384 & & 2.325 & .021 & \\
\hline $\begin{array}{l}\text { Utilitarian } \\
\text { Features }\end{array}$ & .627 & .115 & .523 & 5.466 & .000 & Supported \\
\hline $\begin{array}{l}\text { Hedonic } \\
\text { Features }\end{array}$ & .113 & .104 & .106 & 1.084 & .280 & Rejected \\
\hline Gamification & .093 & .073 & .091 & 1.281 & .202 & Rejected \\
\hline
\end{tabular}

Although other research had found that users tend to seek fun and enjoyment in their web design, this research reflected a result that contradicted with the existing literature in crowdfunding domain (Behl \& Dutta, 2020; Kontogiannidis et al., 2017) The game element applied in the crowdfunding platform did not contribute to influencing the donors' intention. Researchers posit that gamification might fail to influence users' behavior in a website or platform because only a single element was applied (Gallego-Durán et al., 2019). The platform should adopt a fully gamelike platform to achieve the intended behavior, and a single game element is not sufficient to do so (Schell, 2008). Moreover, referring to the similar concept of crowdfunding-crowdsourcing-in which the complexity of game design involving a set of game elements like challenges, achievements, countdowns, discovery, points, reward schedules, and status has contributed to drive users' positive behavioral intentions (Kavaliova et al., 2016; Puritat, 2019). Since crowdfunding in Malaysia is still developing, most of the platforms were designed with basic gamification features.

Next, the results showed that utilitarian features do have a significant impact on the intention to donate to a crowdfunding platform. While, hedonic features demonstrated exactly the opposite - little or no impact on the intention to donate. Contributors in crowdfunding activities appreciate the utilitarian features more than the hedonic features if they wished to use the platform to donate. Features such as website aesthetic design, which emphasized color range, interactive images, and layout that provided enjoyment while using a platform had no impact when it involved financial activities. These findings corresponded to the results in serious context of financial transaction (Yaseen \& El Qirem, 2018). The hedonic attributes of a platform acted as a distraction 
to the user who came to the website to complete their initial behavioral intention. Besides, (Hazari et al., 2017) found in their study that utilitarian features will dominate hedonic features when both factors are evaluated simultaneously. Thus, it can be concluded that the utilitarian design of a website is more important compare to hedonic and gamification features, so the primary emphasis in website design should be on the utilitarian aspects.

This study contributes to knowledge of human computer interaction literature from two perspectives. Theoretically, most of the literature in the crowdfunding context focuses on the tendency of contributors to involve in a crowdfunding project based on the project owners' credibility and characteristics (Haas et al., 2014; Kang et al., 2016; Wang \& Yang, 2019). The current study has shed light on the role of the crowdfunding platform itself as one of the key players in crowdfunding activities to attract contributors and contribute to the success of the project in acquiring funds. Furthermore, this study contributes to the existing literature by explaining that users of the platform emphasized functional and practical features rather than fun and enjoyment features in serious context online activities that involve financial transactions (Hazari et al., 2017; Yaseen \& El Qirem, 2018).

Since the literature on gamification in the crowdfunding domain is still scarce (Kontogiannidis et al., 2017), this study offers a meaningful contribution to the literature. The finding of this study suggests that the single element of gamification feature is inadequate. A full fledge of the game-like platform is better to attract online users to conduct behavioral intention.

On managerial perspectives, a crowdfunding platform manager should emphasize utilitarian features as donors are seeking to fulfill their primary purpose while using the platform. The layout should include the timely updates of the project section as one of the utilitarian features so that donors can ensure that their donation is not manipulated. Furthermore, all crowdfunding platforms should use the same template of information provided by the fund seeker, especially the explanation of how the fund will be used.

Furthermore, to attract and retain donors on the platform, the manager needs to consider including more gamification features, as the current features are insufficient to influence donors' behavior. Features challenges, achievements, countdowns, discovery, points, reward schedules, and status that implied the second type of gamification should be embedded on the platform.

\section{Conclusion}

The objective of this research has been to investigate the crowdfunding platform and its use of utilitarian features, features of gamification, and hedonic features and how they affect donor intention. The study suggested that the fund provider on the platform are not fun-seekers. They complete their task without the assistance of hedonic features. The limitations of gamification features in the crowdfunding platform, on the other hand, meant that the fund provider could not experience a real game-like situation, thus not contributing towards a fund seeker's decision.

Future studies should extend this research. First, since crowdfunding in Malaysia is still at a nascent stage, researchers should test the framework in other research settings that have an advanced crowdfunding environment. Also, academicians should work together with the crowdfunding platform managers to develop a crowdfunding platform that includes a better design of gamification. Second, this study is limited to community-based crowdfunding, and future researchers should investigate other types of crowdfunding. Community-based crowdfunding is solely based on benevolent action, which means donors have no intention to seek a monetary 
return. They are more concerned about completing their donation and fulfilling their primary purpose, to give money to a charity. Meanwhile, investors in equity and lending-based crowdfunding are purposely seeking financial returns. Thus, analyzing their motivation will likely result in different findings.

\section{References}

Adhikary, B. K., Kutsuna, K., \& Hoda, T. (2018). Crowdfunding-types and models. In Crowdfunding: Lessons from Japan's Approach (pp. 9-20). Springer. https://doi.org/10.1007/978-981-13-1522-0_2

Agrawal, A., Catalini, C., \& Goldfarb, A. (2015). Crowdfunding: Geography, Social Networks, and the Timing of Investment Decisions. Journal of Economics and Management Strategy, 24(2), 253-274. https://doi.org/10.1111/jems.12093

Aitamurto, T. (2011). The impact of crowdfunding on journalism: Case study of spot.us, a platform for community-funded reporting. Journalism Practice, 5(4), 429-445. https://doi.org/10.1080/17512786.2010.551018

Althoff, T., \& Leskovec, J. (2015). Donor retention in online crowdfunding communities: A case study of DonorsChoose.org. WWW 2015 - Proceedings of the 24th International Conference on World Wide Web, 34-44. https://doi.org/10.1145/2736277.2741120

Aprilia, Lady, \& Wibowo, S. S. (2017). The impact of social capital on crowdfunding performance. The South East Asian Journal of Management, 11(1). https://doi.org/10.21002/seam.v11i1.7737

Argo, N., Klinowski, D., Krishnamurti, T., \& Smith, S. (2020). The completion effect in charitable crowdfunding. Journal of Economic Behavior and Organization, 172, 17-32. https://doi.org/10.1016/j.jebo.2020.01.025

Attali, Y., \& Arieli-Attali, M. (2015). Gamification in assessment: Do points affect test performance? Computers and Education, 83, 57-63. https://doi.org/10.1016/j.compedu.2014.12.012

Babin, B. J., Darden, W. R., \& Griffin, M. (1994a). Utilitarian shopping value. Journal of Consumer Research, 20(4), 644-657. https://doi.org/DOI: http://dx.doi.org/10.1086/209376

Babin, B. J., Darden, W. R., \& Griffin, M. (1994b). Work and/or Fun: Measuring Hedonic and Utilitarian Shopping Value. Journal of Consumer Research, 20(4), 644-656. https://doi.org/10.1086/209376

Bartel, A., \& Hagel, G. (2014). Engaging students with a mobile game-based learning system in university education. IEEE Global Engineering Education Conference, EDUCON, 957960. https://doi.org/10.1109/EDUCON.2014.6826215

Behl, A., \& Dutta, P. (2020). Engaging donors on crowdfunding platform in Disaster Relief Operations (DRO) using gamification: A Civic Voluntary Model (CVM) approach. International Journal of Information Management, 54, 102140. https://doi.org/10.1016/j.ijinfomgt.2020.102140

Belleflamme, P., Omrani, N., \& Peitz, M. (2015). The economics of crowdfunding platforms. Information Economics and Policy, 33, 11-28.

Bilgihan, A., \& Bujisic, M. (2015). The effect of website features in online relationship marketing: A case of online hotel booking. Electronic Commerce Research and Applications, 14(4), 
222-232. https://doi.org/10.1016/j.elerap.2014.09.001

Bilgihan, A., Kandampully, J., \& Zhang, T. (Christina). (2016). Towards a unified customer experience in online shopping environments: Antecedents and outcomes. International Journal of Quality and Service Sciences, 8(1), 102-119. https://doi.org/10.1108/IJQSS-072015-0054

Bilgihan, A., Okumus, F., Nusair, K., \& Bujisic, M. (2014). Online experiences: Flow theory, measuring online customer experience in e-commerce and managerial implications for the lodging industry. Information Technology and Tourism, 14(1), 49-71. https://doi.org/10.1007/s40558-013-0003-3

Bly, S., Cook, L., Bickmore, T., Churchill, E., \& Sullivan, J. W. (1998). The rise of personal Web pages at work. 313-314. https://doi.org/10.1145/286498.286786

Bridges, E., \& Florsheim, R. (2008). Hedonic and utilitarian shopping goals: The online experience. Journal of Business Research, 61(4), 309-314. https://doi.org/10.1016/j.jbusres.2007.06.017

Bruder, P. (2015). Game on: Gamification in the classroom. The Education Digest, 80(7), 56.

Burtch, G., Ghose, A., \& Wattal, S. (2013). An Empirical Examination of the Antecedents and Consequences of Investment Patterns in Crowd-Funded Markets. Information Systems Research, 24(3), 499-519. https://doi.org/http://dx.doi.org/10/1287/isre.1120.0468

Burtch, G., Hong, Y., \& Liu, D. (2018). The Role of Provision Points in Online Crowdfunding. Journal of Management Information Systems, 35(1). https://doi.org/10.1080/07421222.2018.1440764

Childers, T. L., Carr, C. L., Peck, J., \& Carson, S. (2001). Hedonic and utilitarian motivations for online retail shopping behavior. Journal of Retailing, 77(4), 511-535. https://doi.org/10.1016/S0022-4359(01)00056-2

Choy, K., \& Schlagwein, D. (2016). Crowdsourcing for a better world: On the relation between IT affordances and donor motivations in charitable crowdfunding. Information Technology and People, 29(1), 221-247. https://doi.org/10.1108/ITP-09-2014-0215

Collins, L., \& Pierrakis, Y. (2012). The venture crowd: Crowdfunding equity investments into business (p. 36). NESTA.

Cortina, J. M. (1993). What Is Coefficient Alpha? An Examination of Theory and Applications. Journal of Applied Psychology, 78(1), 98. https://doi.org/10.1037/0021-9010.78.1.98

Cózar-Gutiérrez, R., \& Sáez-López, J. M. (2016). Game-based learning and gamification in initial teacher training in the social sciences: an experiment with MinecraftEdu. International Journal of Educational Technology in Higher Education, 13(1), 2. https://doi.org/10.1186/s41239-016-0003-4

Cruz-Cárdenas, J., Guadalupe-Lanas, J., Ramos-Galarza, C., \& Palacio-Fierro, A. (2021). Drivers of technology readiness and motivations for consumption in explaining the tendency of consumers to use technology-based services. Journal of Business Research, 122, 217-225. https://doi.org/10.1016/j.jbusres.2020.08.054

Dale, S. (2014). Gamification: Making work fun, or making fun of work? Business Information Review, 31(2), 82-90. https://doi.org/10.1177/0266382114538350

Deterding, S., Dixon, D., Khaled, R., \& Nacke, L. (2011). From game design elements to gamefulness: Defining "Gamification." Proceedings of the MindTrek Conference 2011, 915. https://doi.org/10.1145/2181037.2181040

Ettis, S. A., \& Haddad, M. M. (2019). Utilitarian and hedonic customer benefits of e-insurance: A look at the role of gender differences. International Journal of E-Business Research, 15(1), 
109-126. https://doi.org/10.4018/IJEBR.2019010107

Fogg, B. (2009). A behavior model for persuasive design. ACM International Conference Proceeding Series, 350, 1-7. https://doi.org/10.1145/1541948.1541999

Forbes, H., \& Schaefer, D. (2017). Guidelines for Successful Crowdfunding. Procedia CIRP, 60, 398-403. https://doi.org/10.1016/j.procir.2017.02.021

Gallego-Durán, F. J., Villagrá-Arnedo, C. J., Satorre-Cuerda, R., Compañ-Rosique, P., MolinaCarmona, R., \& Llorens-Largo, F. (2019). A guide for game-design-based gamification. Informatics, 6(4), 49. https://doi.org/10.3390/informatics6040049

Gleasure, R., \& Feller, J. (2016). Does Heart or Head Rule Donor Behaviors in Charitable Crowdfunding Markets? International Journal of Electronic Commerce, 20(4), 499-524. https://doi.org/10.1080/10864415.2016.1171975

Ha, S., \& Stoel, L. (2009). Consumer e-shopping acceptance: Antecedents in a technology acceptance model. Journal of Business Research, 62(5), 565-571. https://doi.org/10.1016/j.jbusres.2008.06.016

Haas, P., Blohm, I., \& Leimeister, J. M. (2014). An empirical taxonomy of crowdfunding intermediaries. 35th International Conference on Information Systems "Building a Better World Through Information Systems", ICIS 2014, 1-18.

Hamari, J., Koivisto, J., \& Sarsa, H. (2014). Does gamification work? - A literature review of empirical studies on gamification. Proceedings of the Annual Hawaii International Conference on System Sciences, 3025-3034. https://doi.org/10.1109/HICSS.2014.377

Hamari, J., \& Tuunanen, J. (2012). Player Types: A Meta-synthesis. Proceedings of Nordic Digra 2012 Conference: Games in Culture and Society, 29-53.

Han, M., Wu, J., Wang, Y., \& Hong, M. (2018). A model and empirical study on the user's continuance intention in Online China Brand communities based on customer-perceived benefits. Journal of Open Innovation: Technology, Market, and Complexity, 4(4), 46-76. https://doi.org/10.3390/joitmc4040046

Hanus, M. D., \& Fox, J. (2015). Assessing the effects of gamification in the classroom: A longitudinal study on intrinsic motivation, social comparison, satisfaction, effort, and academic performance. Computers and Education, 80, 152-161. https://doi.org/10.1016/j.compedu.2014.08.019

Hazari, S., Bergiel, B. J., \& Sethna, B. N. (2017). Hedonic and utilitarian use of user-generated content on online shopping websites. Journal of Marketing Communications, 23(6), 572591. https://doi.org/10.1080/13527266.2016.1143383

Hsu, C. L., \& Chen, M. C. (2018). How does gamification improve user experience? An empirical investigation on the antecedences and consequences of user experience and its mediating role. Technological Forecasting and Social Change, 132(November 2017), 118-129. https://doi.org/10.1016/j.techfore.2018.01.023

Hsu, C. L., Chen, Y. C., Yang, T. N., \& Lin, W. K. (2017). Do website features matter in an online gamification context? Focusing on the mediating roles of user experience and attitude. Telematics and Informatics, 34(4), 196-205. https://doi.org/10.1016/j.tele.2017.01.009

Isaacs, S. (2015). The Difference Between Gamification And Game-Based Learning. An International Education Association (ASCD). https://inservice.ascd.org/the-differencebetween-gamification-and-game-based-learning/

Jamshidi, D., Keshavarz, Y., Kazemi, F., \& Mohammadian, M. (2018). Mobile banking behavior and flow experience: An integration of utilitarian features, hedonic features and trust. International Journal of Social Economics, 45(1), 57-81. https://doi.org/10.1108/IJSE-10- 
2016-0283

Jang, S., Kitchen, P. J., \& Kim, J. (2018). The effects of gamified customer benefits and characteristics on behavioral engagement and purchase: Evidence from mobile exercise application uses. Journal of Business Research, 92, 250-259. https://doi.org/10.1016/j.jbusres.2018.07.056

Jian, L., \& Shin, J. (2015). Motivations behind donors' contributions to crowdfunded journalism. Mass Communication and Society, 18(2), 165-185. https://doi.org/10.1080/15205436.2014.911328

Jiang, H., Wang, Z., Yang, L., Shen, J., \& Hahn, J. (2020). How Rewarding Are Your Rewards? A Value-Based View of Crowdfunding Rewards and Crowdfunding Performance. Entrepreneurship: Theory and Practice. https://doi.org/10.1177/1042258720928922

Kang, M. H., Gao, Y., Wang, T., \& Zheng, H. (2016). Understanding the determinants of funders' investment intentions on crowdfunding platforms: A trust-based perspective. Industrial Management and Data Systems, 116(8), 1800-1819. https://doi.org/10.1108/IMDS-072015-0312

Kavaliova, M., Virjee, F., Maehle, N., \& Kleppe, I. A. (2016). Crowdsourcing innovation and product development: Gamification as a motivational driver. Cogent Business and Management, 13(8), 1128132. https://doi.org/10.1080/23311975.2015.1128132

Kim, H. W., Gupta, S., \& Koh, J. (2011). Investigating the intention to purchase digital items in social networking communities: A customer value perspective. Information and Management, 48(6), 228-234. https://doi.org/10.1016/j.im.2011.05.004

Kim, K., \& Ahn, S. J. (Grace). (2017). The role of gamification in enhancing intrinsic motivation to use a loyalty program. Journal of Interactive Marketing, 40, 41-51. https://doi.org/10.1016/j.intmar.2017.07.001

Kim, P. H., Buffart, M., \& Croidieu, G. (2016). TMI: Signaling Credible Claims in Crowdfunding Campaign Narratives. Group and Organization Management, 41(6), 717-750. https://doi.org/10.1177/1059601116651181

Koivisto, J., \& Hamari, J. (2019). The rise of motivational information systems: A review of gamification research. International Journal of Information Management, 45, 191-210. https://doi.org/10.1016/j.ijinfomgt.2018.10.013

Kontogiannidis, P., Theriou, G., \& Sarigiannidis, L. (2017). Crowdfunding: Exploring the factors associated with the users' intention to finance a project online. International Journal of Web Based Communities, 13(1), 73-101. https://doi.org/10.1504/IJWBC.2017.082721

Kuppuswamy, V., \& Bayus, B. L. (2018). Crowdfunding creative ideas: The dynamics of project backers. The Economics of Crowdfunding: Startups, Portals and Investor Behavior, 151182. https://doi.org/10.1007/978-3-319-66119-3_8

Kuznetsov, V. V. (2020). Effect of digitalization on the competitiveness of money transfer operators in the national payment system. International Journal on Emerging Technologies, 11(2), 674-677.

Lacan, C., \& Desmet, P. (2017). Does the crowdfunding platform matter? Risks of negative attitudes in two-sided markets. Journal of Consumer Marketing, 34(6), 472-479. https://doi.org/10.1108/JCM-03-2017-2126

Landers, R. N., Bauer, K. N., \& Callan, R. C. (2017). Gamification of task performance with leaderboards: A goal setting experiment. Computers in Human Behavior, 71, 508-515. https://doi.org/10.1016/j.chb.2015.08.008

Liu, D., Santhanam, R., \& Webster, J. (2017). Toward meaningful engagement: A framework for 
design and research of gamified information systems. MIS Quarterly: Management Information Systems, 41(4), 1011-1034. https://doi.org/10.25300/MISQ/2017/41.4.01

Lukkarinen, A., Teich, J. E., Wallenius, H., \& Wallenius, J. (2016). Success drivers of online equity crowdfunding campaigns. Decision Support Systems, 87, 26-38. https://doi.org/10.1016/j.dss.2016.04.006

Mariani, A., Annunziata, A., Aprile, M. C., \& Nacchia, F. (2017). Crowdfunding and wine business: Some insights from Fundovino experience. Wine Economics and Policy, 6(1), 60-70. https://doi.org/10.1016/j.wep.2017.02.001

Mekler, E. D., Brühlmann, F., Opwis, K., \& Tuch, A. N. (2013). Do points, levels and leaderboards harm intrinsic motivation?: an empirical analysis of common gamification elements. Gamification '13: Proceedings of the First International Conference on Gameful Design, Research, and Applications, 66-73.

Mollick, E. (2014). The dynamics of crowdfunding: An exploratory study. Journal of Business Venturing, 29(1), 1-16. https://doi.org/10.1016/j.jbusvent.2013.06.005

Ozturk, A. B., Nusair, K., Okumus, F., \& Hua, N. (2016). The role of utilitarian and hedonic values on users' continued usage intention in a mobile hotel booking environment. International Journal of Hospitality Management, 57, 106-115. https://doi.org/10.1016/j.ijhm.2016.06.007

Polzin, F., Toxopeus, H., \& Stam, E. (2018). The wisdom of the crowd in funding: information heterogeneity and social networks of crowdfunders. Small Business Economics, 50(2), 251-273. https://doi.org/10.1007/s11187-016-9829-3

Powers, K. L., Brooks, P. J., Aldrich, N. J., Palladino, M. A., \& Alfieri, L. (2013). Effects of videogame play on information processing: A meta-analytic investigation. Psychonomic Bulletin and Review, 40(6), 1055-1079. https://doi.org/10.3758/s13423-013-0418-z

Puritat, K. (2019). A gamified mobile-based approach with web monitoring for a crowdsourcing framework designed for urban problems related smart government: A case study of Chiang Mai, Thailand. International Journal of Interactive Mobile Technologies, 13(12), 55-66. https://doi.org/10.3991/ijim.v13i12.10989

Rakjit, K., \& Lertputtarak, S. (2019). Generation c's internet searching behavior and the factors influencing the intention to follow electronic word-of-mouth in online hotel reservations. ABAC Journal, 39(4), 70-89.

Rodrigues, L. F., Oliveira, A., \& Costa, C. J. (2016). Playing seriously - How gamification and social cues influence bank customers to use gamified e-business applications. Computers in Human Behavior, 63, 392-407. https://doi.org/10.1016/j.chb.2016.05.063

Rodriguez-Ricardo, Y., Sicilia, M., \& López, M. (2018). What drives crowdfunding participation? The influence of personal and social traits. Spanish Journal of Marketing - ESIC, 22(2), 163-182. https://doi.org/10.1108/SJME-03-2018-004

Schell, J. (2008). The art of game design: A book of lenses. In The Art of Game Design: A Book of Lenses (pp. 1-489). Elsevier. https://doi.org/10.1201/9780080919171

Scholl-Grissemann, U., \& Schnurr, B. (2016). Room with a view: how hedonic and utilitarian choice options of online travel agencies affect consumers' booking intentions. International Journal of Culture, Tourism, and Hospitality Research, 10(11), 361-376. https://doi.org/10.1108/IJCTHR-06-2016-0062

Stiver, A., Barroca, L., Minocha, S., Richards, M., \& Roberts, D. (2015). Civic crowdfunding research: Challenges, opportunities, and future agenda. New Media and Society, 17(2), 249-271. https://doi.org/10.1177/1461444814558914 
Thiel, S. K., \& Fröhlich, P. (2017). Gamification as motivation to engage in location-based public participation? Lecture Notes in Geoinformation and Cartography, 399-421. https://doi.org/10.1007/978-3-319-47289-8_20

Venkatesh, V., \& Brown, S. A. (2001). A longitudinal investigation of personal computers in homes: Adoption determinants and emerging challenges. MIS Quarterly: Management Information Systems, 25(1), 71-98. https://doi.org/10.2307/3250959

Vieira, V., Santini, F. O., \& Araujo, C. F. (2018). A meta-analytic review of hedonic and utilitarian shopping values. Journal of Consumer Marketing, 35(4), 426-437. https://doi.org/10.1108/JCM-08-2016-1914

Wang, Z., \& Yang, X. (2019). Understanding backers' funding intention in reward crowdfunding: An elaboration likelihood perspective. Technology in Society, 58, 101149. https://doi.org/10.1016/j.techsoc.2019.101149

Wu, J., \& Holsapple, C. (2014). Imaginal and emotional experiences in pleasure-oriented IT usage: A hedonic consumption perspective. Information and Management, 51(1), 80-92. https://doi.org/10.1016/j.im.2013.09.003

Wu, W. Y., Lee, C. L., Fu, C. su, \& Wang, H. C. (2013). How can online store layout design and atmosphere influence consumer shopping intention on a website? International Journal of Retail \& Distribution Management, 42(1), 4-24. https://doi.org/10.1108/IJRDM-01-20130035

Xi, N., \& Hamari, J. (2020). Does gamification affect brand engagement and equity? A study in online brand communities. Journal of Business Research, 109, 449-460. https://doi.org/10.1016/j.jbusres.2019.11.058

Yaseen, S. G., \& El Qirem, I. A. (2018). Intention to use e-banking services in the Jordanian commercial banks. International Journal of Bank Marketing, 36(3), 557-571. https://doi.org/10.1108/IJBM-05-2017-0082

Zhang, H., \& Chen, W. (2019). Backer Motivation in Crowdfunding New Product Ideas: Is It about You or Is It about Me? Journal of Product Innovation Management, 36(2), 241-262. https://doi.org/10.1111/jpim.12477

Zhao, L., \& Vinig, T. (2017). Hedonic value and crowdfunding project performance: a propensity score matching-based analysis. Review of Behavioral Finance, 9(2), 169-186. https://doi.org/10.1108/RBF-09-2016-0059

Zhao, Q., Chen, C. Der, Wang, J. L., \& Chen, P. C. (2017). Determinants of backers' funding intention in crowdfunding: Social exchange theory and regulatory focus. Telematics and Informatics, 34(1), 370-384. https://doi.org/10.1016/j.tele.2016.06.006

Zheng, X., Men, J., Yang, F., \& Gong, X. (2019). Understanding impulse buying in mobile commerce: An investigation into hedonic and utilitarian browsing. International Journal of Information Management, 48, 151-160. https://doi.org/10.1016/j.ijinfomgt.2019.02.010 